\title{
Farmer Community Empowerment as a Result of a Regional Food Security Policy in Purwakarta Regency
}

\author{
Wahyu Gia Uliantoro*, Nita Nurliawati, Endah Mustika Ramdani, Sindy Valenita, Ashila Azka Cahyawijaya \\ Administrasi Pembangunan Negara \\ STIA LAN Bandung Polytechnic \\ Bandung, Indonesia \\ *wahyugia@yahoo.com
}

\begin{abstract}
Recently, the farming community in Purwakarta is still less fortunate, if not in the poor category. However, through The Tangguh Village Program, the farming community has been risen up and become empowered in facing agricultural problems and purchasing power. The objective of the research is to find out the empowerment of the farming community in the program, and to measure the level of community empowerment in implementing policies and program for regional defence resilience. This research was conducted through an explanatory survey, to find definite answers to problems in the research area. The problem examined is the relationship between programs of regional policies on the influence of empowerment of farmer communities. The Tangguh Village Program is expected to encourage village to become fortresses of food security, especially in the face of the decline in purchasing power caused by the Covid-19 pandemic. The of this study describes the organization, management, and empowerment of The Purwakarta Regency farmer community in increasing regional food security.
\end{abstract}

Keywords-regional policies, food security, tangguh village program, empowerment, farmer welfare

\section{INTRODUCTION}

Long before Indonesia's independence, precisely on April 27, 1952, when the ground-breaking of the Faculty of Agriculture Building, University of Indonesia in Bogor, Bung Karno has reminded us of all that food is a matter of dying a nation's life. Be warned further that if food needs are not met, then catastrophe. Therefore, according to the Founding Father of the Nation it takes a massive effort, radical and revolutionary. Even "sufficient" access to food is a Human Azazi Right that must always be guaranteed by the state alongside the community [1].

Since then, the United Nations general assembly on September 25, 2015, in New York, the United States has officially endorsed the Sustainable Development Goals (SDGs) as a global development agreement. The concept of SDGs continues the previous development concept of Millennium Development Goals (MDGs).
There are five main foundations of SDGs namely human, planetary, welfare, peace, and partnership. Furthermore, there are seventeen objectives of SDGs. That hopefully in the future there will be no poverty of any kind around the world. There is no hunger, so efforts are needed to achieve food security to support nutrition improvement and encourage sustainable agricultural cultivation.

Based on the commitment listed in the concept of SDGs, it is clear that food security is one of the global challenges that needs to be anticipated by various parties around the world. Indonesia is no exception.

Furthermore, in order to realize an independent, advanced, fair, and prosperous Indonesian society through accelerated development in various fields by emphasizing the establishment of a solid economic structure, based on competitive ability in various regions supported by quality and competitive human resources. The focus of RPJMN $2020-$ 2024 development is five namely human developments, economic development, regional development, infrastructure development, as well as political, legal, defence and security development.

Food development is part of the focus of economic development that can strengthen and support human development and security defence by paying attention to aspects of regional development, infrastructure, politics, and law. Based on the series of interconnectedness and urgency of the global and national level development agenda in the long, medium, and even short term at this time in the Covid 19 Pandemic, research of the State Development Administration Study Program takes the topic of Scenario Planning of Food Security Development through Strengthening Food Sovereignty Policy and Institutional Harmonization taken. Hopefully, we can learn wisdom from the Covid 19 pandemic.

When referring to the data submitted by Jacques Diouf one of the Fao Director General or the World Food and Agriculture Security Agency on World Food Day 16 October 2010 in Rome that there are 925 million people living in chronic 
hunger and malnutrition. Then 100 states of emergency threatened agricultural production and 30 countries in a state of food crisis. Therefore, to avoid the danger of global hunger, agricultural production must increase by $70 \%$ and double in developing countries, including Indonesia. If it turns out that what happens is crop failure everywhere, then the food crisis will actually hit even worse.

Looking at the condition of Indonesia with a population of approximately 267 million people where the proportion of the poor is still large and dependence on rice consumption is still high, followed by the problem of malnutrition and or overnutrition on the other hand, the increase in food demand both in terms of quantity, quality, diversity, and safety needs to be anticipated better. While in terms of supply there is an increase in land conversion, access to sources of financing, technology, information, and the market is relatively unbalanced. Plus, the uneven distribution of food production both between regions and between times exacerbated by the negative impacts of climate change. Therefore, there needs to be a breakthrough and strengthening of policies in anticipation of various possibilities in the future with regard to the Food Security Development Program in Indonesia.

The development of food security, which heeds the process of strengthening food sovereignty policy, is relatively less robust. Similarly, food security without systematic efforts to build a bridge of food independence through institutional harmonization efforts becomes incomplete.

The selection of locus in Purwakarta Regency based on consideration of purwakarta district no. 15 of 2013 concerning Regional Medium Term Development Plan (RPJMD) purwakarta year 2018-2023 stated that the vision of the Regent of Purwakarta is "REALIZING PURWAKARTA ISTIMEWA" is to exert all the potential that exists in order to achieve a condition of the region with the order of Purwakarta Special in values that are reality, not only from the textual side, but must be more applicative.

In order to build food security, the focus of food security development is one of them is on community empowerment. Community empowerment in food security means increasing the independence and capacity of the community to play an active role in realizing the availability, distribution, and consumption of food over time.

To measure community empowerment there are several operational domains including, Participation, Leadership, Mobilization of Resources, Organizational Structure, needs assessment, Awareness for critical thinking, and partnerships with other organizations [2].

Along with regional autonomy, the empowerment process is decentralized in accordance with the potential and diversity of regional resources. Likewise, regarding the opportunity to try, that the efforts made not necessarily on rice farming, but also non-rice farming (on-farm), off farm even non-farm. In essence, efforts to improve food security do not focus on agricultural development in the primary sense, but also agribusiness systems and businesses [3]. The empowerment of food security that runs in Purwakarta district is in line with the focus of empowerment is not only on farm but also off farm empowerment.

Community empowerment in agriculture is important considering the role of farmer groups to contribute to the process of food security development. Some of the problems that occur include:

- Field farm has not been utilized to the maximum. The increase in population and industrial development can lead to the transfer of agricultural land functions into settlements, industry, and trade.

- The interest of the younger generation in agriculture is so lacking that the regeneration of farmers is slow.

- Counselling staff is decreasing.

- Application of agricultural technology on farm and off farm at the farmer level is still low and less even.

- Still low value-added increase for some non-rice agricultural products.

- Marketing (post-harvest is still minimal). Therefore, this study wants to see another thing that is the result of empowerment of farmer groups in maintaining food security in Purwakarta regency.

\section{RESEARCH METHODS}

The research method used in this research is qualitative descriptive with System Thinking approach. The essence of system thinking is that (1) simplifying the complexity of realworld complexity without losing the core of the system itself, (2) the learning processes defined as a process of change to replace the old way of thinking in a new way. According to McNamara [4], Systems Thinking is fundamentally a way of helping people to view the world, including its organization from a broad perspective involving structures, patterns, and events rather than just looking at the events.

To support this research, the data was obtained through interviews conducted to informants, namely officials at the Department of Food Security and Agriculture purwakarta. The selection of the informant is based on purposive techniques in which the informant is chosen based on the ownership of information useful for research. In addition, other data is also obtained from relevant documents as a source of supporting reference. In this study, questionnaires were also distributed to the public related to food security development. The use of triangulation of data sources and methods becomes a way for researchers to ascertain the correctness or validity of the data. This research is expected to provide a comprehensive overview of the strategies carried out by the Purwakarta Regency Government in encouraging community empowerment on food security development. 


\section{RESULTS AND DISCUSSION}

Based on the data obtained, about the welfare level of the farmers by using indicators from the Agency Central Statistics 2005 which consists of Income, Expenses, State of Place residence, residential facilities, ease of getting facilities health, health of family members, easy access education, easy access transportation access can be inferred as follows:

- The main income of the respondent the farmer community is classified as low with an average score of 1 , this is because agricultural products are still low and management of agricultural areas is not intensive and is carried out in a manner traditional, to meet their needs this farming community uses income other than the results of their efforts do, apart from that in part this farming community too empowering family members others like a wife or child for work help in order to add revenue for meet their daily needs.

- Home consumption or expenses the stairs are classified as low by value average score 1 . The amount of expenditure issued by a house the stairs describe the level household welfare concerned. The higher it is expenses incurred for non-food needs indicate there is an increase in welfare the household. Some of the farmers here have high more expenses compared to the amount of income received from the results farming, the farmer's expenses are partly great use for necessities eat every day.

- The condition of the residence of the average farmer is classified as permanent with value Average 3. Housing conditions reflects the condition of well-being someone, the better the place his stay could be said to have good welfare too. Circumstances the residence is there to be seen from type of building. There are three categories classification of types of houses namely permanent, semi-permanent and not permanent. Different types of categories this residence is visible from the walls, floor, and roof. In the district Darang and most of the farming community occupy their own houses with the type of permanent building, namely walled house, tiled floors, and tile roofs.

- Ease of getting food with a score of 2. Food security has a different role very important for a success social development including facilities and infrastructure agriculture which is increasingly rapidly going effect in improving economy in each region, that is indirectly it will effect on level the welfare of the local community. Most of the farming community is sufficient easy to get food needs and means of transportation because the road is already on asphalt but in the absence public transportation such as public transport so that little traveling activity hampered but this can be overcome by the presence of motorbike taxis.

Efforts to increase the empowerment of farmers is an effort to improve the formation of mental attitudes through self- reliant attitudes in trying. We can know that the way or system of farming until now in general is still traditional. As stated by Zahriyani [5] that one of the fundamental challenges facing Indonesia in the agricultural sector is the lack of number and low quality of agricultural human resources compared to other sectors. This can be seen from the fact that most Indonesian farmers live below the poverty line and are unable to improve their standard of living due to previously described factors.

Efforts to improve the empowerment of farmers must be followed by good institutions. In the life of the farmer community, the position and institutional function of farmers is part of the social structure that facilitates social interaction in a community.

One of the stakeholders in farmer institutions is extension agencies. Currently, the decrease of government extension workers in the field causes innovation gaps to rapid information change and decreased effectiveness of counselling activities. As a result, farmers are powerless in dealing with changes in their own environment, especially with regard to farming, so the role of extension workers is still needed by farmers to overcome this.

With the reduction of extension workers, Syahyuti [6] stated that the right extension for now and reliable in conveying the message of innovation is the extension that comes from the farmer itself. Farmers with advanced traits then act as self-help extension and conduct self-help counselling. A study assessed, self-help extension is able to play a role in counselling to farmers so that the process of dissemination of technological innovation and farmer-to-farmer learning system tends to be smoother and more sustainable [7].

Based on the results of surveys and interviews, Purwakarta has begun to empower the community in an effort to improve farmers' welfare and food security. The Regent continues to give direction to DISPANGTAN groups and farmers. DISPANGTAN as a government extension worker always accompanies and provides a forum for farmer groups to conduct discussions related to problems in the field.

The approach of community empowerment in development means that people are placed in the position of actors and beneficiaries of the process of finding solutions and achieving development results. Thus, the community must be able to increase self-reliance to overcome the problems faced. Indonesia, the development of farmer empowerment is known as the extension program.

The culmination of direct or indirect influence of the implementation of counselling is Indonesia's success in achieving food self-sufficiency, namely internationally recognized rice at the $1985 \mathrm{FAO}$ session in Rome [8].

This is relevant to Purwakarta which has the slogan "No day without planting, no day without harvest". This proves that Purwakarta as the best area in improving the achievement of planting area. Since 2016, the surplus of rice in Purwakarta is approximately $25 \%$ of production. Based on the results of an interview with the Head of The Food Security Office of 
Purwakarta (November 11, 2020), the farming community in Purwakarta also tried to develop some potential as an advantage of crops other than rice such as coffee and mangosteen, even some have been sent abroad. From the statement, it can be known that the farming community of Purwakarta District has had efforts to increase the potential of the village by developing crops other than rice.

The interaction between the government and the farming community is one of the evidences that there has been collaboration between the government and the farming community in the village. Strong commitment from the government and the community for food security development can be seen from several harvest increases in Purwakarta District.

The results of the survey of respondents showed that conducted by DISPANGTAN as shown in the diagram above. Survey data shows that the types of activities carried out by DISPANGTAN for farmer groups amounted to 87 (eightyseven) percent in the form of counselling and 13 (thirteen) percent in the form of discussion or sharing. It shows that there is concern from DISPANGTAN to farmers groups in running their business.

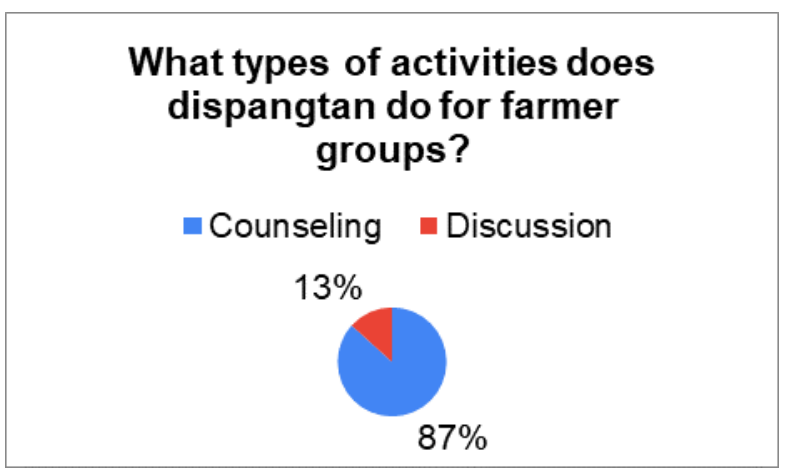

Fig. 1. Questionnaire result chart.

Then, various communications conducted by DISPANGTAN according to farmer groups are shown with 67 (sixty-seven) percent conducted by direct communication, then 20 (twenty) percent is done indirectly i.e., by phone call or communication through social media, and the last 13 (thirteen) percent communicates in combination between directly and also indirectly through phone calls and social media.

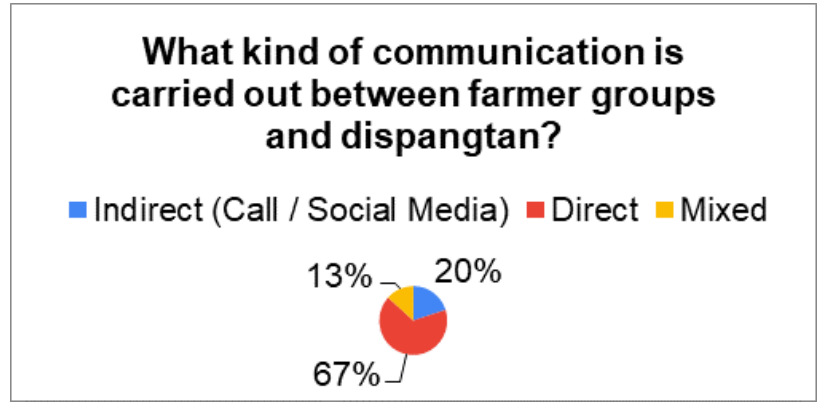

Fig. 2. Questionnaire result chart.

\section{CONCLUSION}

Based on the above discussion, Purwakarta Regency has been able to empower farmers through various programs. Purwakarta Regency government synergizes with farmer groups in creating food security in their areas.

The Regent continues to give direction to DISPANGTAN groups and farmers. DISPANGTAN as a government extension worker always accompanies and provides a forum for farmer groups to conduct discussions related to problems in the field. Purwakarta farmers have made efforts to increase the potential of the village by developing crops other than rice.

Although the condition of extension workers is currently reduced, purwakarta regency is able to establish interactions between the government and farmers so that collaboration is established in improving food availability and community welfare in Purwakarta Regency.

\section{REFERENCES}

[1] W.J. Byron, "Twin towers: A philosophy and theology of business," Journal of Business Ethics, vol. 7, no. 7, pp. 525-530, 1988

[2] G. Laverack, "An identification and interpretation of the organizational aspects of community empowerment," Community development journal, vol. 36, no. 2, pp. 134-145, 2001.

[3] R. Tauchid, Die neuen Acrylfarben: alles über die neue Generation der Acrylfarben. Ed. Michael Fischer, 2007.

[4] E. Trilestari and L. Almamalik, Systems Thinking :Suatu Pendekatan Permasalahan yang Kompleks dan Dinamis. Bandung: STIA LAN Bandung Press, 2008

[5] P. Zahriyani, Pembangunan Pertanian di Era Globalisasi. Penerbit PT Pelita Harapan, 2009.

[6] S. Syahyuti, "Peran Strategis Penyuluh Swadaya dalam Paradigma Baru Penyuluhan Pertanian Indonesia,” Jurnal Agro Ekonomi, vol. 32, no. 1, pp. 43-58, 2014

[7] B. Lukuyu, F. Place, S. Franzel and E. Kiptot, "Disseminating improved practices: are volunteer farmer trainers effective," The Journal of Agricultural Education and Extension, vol. 18, no. 5, pp. 525-540, 2012.

[8] R.Z. Ahmad, Z. Arifin and R. Pambudy, Improvement of nutrient content in quail feces by storage. In Seminar Nasional Peternakan dan Veteriner, Bogor (Indonesia), 18-19 Nov 1997. PUSLITBANGNAK, 1998 